\title{
Fiscal Instruments of a Support of the Families with Children and their Changes in Developed Countries ${ }^{\#}$
}

\author{
Leoš VÍTEK ${ }^{*}$
}

\section{Introduction}

Developed countries are faced with a low and declining birth rate. This effect is determined by various factors, one of which being also costs (financial, time-related, opportunity, etc.) associated with caring for children. Therefore, governments usually try to use fiscal instruments to support the families with children. However, according to a number of authors - see e.g. Carone - Salomaki (2004), Sirovátka - Žižlavský (2003) - fiscal instruments also affect the work effort and labour demand. These effects are even more serious in the current situation, when due to the economic turmoil in developed countries there comes to an increase in unemployment.

Problems associated with (de)stimulative effects of taxes, insurance premia and benefits arise also due to the fact that because of various reasons, these instruments are not effectively coordinated and often operate in opposite directions (Carone - Salomaki, 2004). It is also not immediately clear whether interaction of the tax, insurance and benefit systems affect differently the short-term and the long-term unemployment. This question is important also because in many European countries there currently rapidly increases the long-term unemployment. Taxation of the labour force have - mainly through the employment - impacts also on the economic growth (Prescott, 2004),

\footnotetext{
\# The article is processed as an output of the research project Impact of the Interaction of Tax and Benefit Systems on an Increase in Motivation towards the Labour Market Participation and on a Family Behaviour registered by the Ministry of Labour and Social Affairs of the Czech Republic under the evidence registration number HC185/10.

Doc. Ing. Leoš Vítek, Ph.D. - associate professor; Department of Public Finance, Faculty of Finance and Accounting, University of Economics, Prague, W. Churchill Sq. 4, 13067 Prague 3, Czech Republic; <leos.vitek@vse.cz>.
} 
which fact is in the context of the long-term slowdown in the growth of EU economies important.

The article aims to analyse changes in fiscal instruments of a support of the families with children in developed countries over the past decade and to focus on the development of selected tax-benefit indicators that describe the fundamental characteristics of the taxation of the families with children. Tax and insurance systems have different distribution as well as (de)stimulative effects within individual countries and for different households. Given that the universal, family-type social benefits often take the form of negative taxes, it is appropriate for the analysis of these impacts to take into account also such type of family benefits.

The article is divided into three main parts. After the introduction and elementary overview of the theory and research in this field (in this section is also included a brief discussion on the advantages and disadvantages of various fiscal instruments of a support of the families with children) follows a section devoted to the description and analysis of the evolution of tax-benefit systems in developed countries. The next section focuses on a more detailed overview of changes in taxes, insurance premia and benefits in selected countries while the attention is focused on reforms aimed at the low-income families with multiple children. Finally, the paper is closed by a conclusion.

\section{Theory and Literature Overview}

The theory in a neoclassical microeconomic concept assumes that the labour demand and labour supply are affected by taxes and benefits in different ways. As shown by Kubátová (2010), taxes imposed on the labour supply (personal income tax and insurance premia paid by employees, indirectly obviously any taxes shifted on a labour-offering employee) shift under the base case the supply curve to the left and thus reduce the work effort. Taxes imposed on the labour demand (in particular insurance premia paid by employers, theoretically also other taxes) will also lead to the shift of the curve to the left and reduce the demanded volume of labour.

Benefit systems may have different impacts on the labour supply - it depends whether the benefits are tied to the work effort. Lump sum (flat) benefits that are paid universally may lead in certain circumstances to inactivity (an inactivity trap in the case of unemployment benefits or 
subsistence minima), in other cases they may not have a significant impact on the work effort (family allowances) - see Jahoda (2004). Benefits linked to the work effort should not adversely affect the labour supply. By their linkage to the work effort, however, they largely lose their redistributive function.

In addition to stimulation towards a specific behaviour and redistribution purposes, specific tax allowances will likely stimulate average taxpayers to rather work - not only because they reduce the effective rate of taxation (average tax rates), but the option of their use presumes an economic activity.

Intensity of the response of a supply and demand to the change in taxes or transfers obviously depends on the elasticity of a supply and demand - the higher the elasticity, the more sensitive are employees or employers to the introduced changes and the stronger is their response.

Macroeconomic testing of the impact of taxes and benefits on employment using econometric models is based primarily on the impact of tax wedges and effective average tax rates on the (un)employment. An overview of these studies may be found e.g. in OECD (2006) and a link to the ongoing economic recession in OECD (2009).

Governments in developed countries use different instruments to support the families with children (with respect to the change in the structure of fiscal policy, most recently see Alesina - Ardagna, 2010). These instruments, reflected in calculations of various micro and macro indicators, are according to the type of a given fiscal instrument possible to divide into:

- allowances or tax credits for dependent partners or children,

- including: differentiated allowances or credits depending on the number of children,

- different rates or bracket limits for various family types,

- including: reduction in premia rates depending on the number of children, 
- splitting of tax bases according to the number of household members (splitting, joint taxation),

- possibility of specific tax allowances aimed at children or a care for them (towards study, child care, etc.),

- universal or mean tested family benefits,

- progressive family benefits depending on the number of children.

The main advantage of the most common, globally provided instruments - allowances, credits, or even benefits - is their administrative simplicity and a positive impact on all the families with children. As the main disadvantage may be considered their global impact - provided these instruments do not focus only on low-income households, they are fiscally costly and ceteris paribus due to the budgetary reasons do not allow providing a strong support for the truly needy low-income families with multiple children. Testing of a family income for the payment of family benefits can therefore be useful not only as an instrument of budgetary savings, but especially for a redistribution and better targeting of public resources on the most needed families - i.e. the families with more than two children that are the most frequently affected by a low standard of living.

Some countries (Netherlands, Italy) used also progressively rising allowances or credits for children, depending on the number of children. This instrument is useful for pursuing several objectives. First, it supports earning families, i.e. reduces the possibility of a fall into the inactivity trap. Secondly, it is relatively low demanding on the budget resources as it focuses only on the third and further children. Thirdly, due to the relatively low number of involved individuals (children) it has a potential to become a very strong instrument.

Another, in the praxis of developed countries relatively often implemented instrument, is a joint taxation of families (or the so-called splitting). This instrument makes sense only in systems with progressive rates - i.e. it cannot be applied for example in the Czech Republic. This instrument is problematic for two reasons: first, it is relatively complex, both for a tax administration and taxpayers, and secondly, it is usually not limited only to low-income households and thus it provides the highest effective support mainly to the families with an above-average earning male partner and a non-earning female partner. This, however, does not correspond with the main objectives of these instruments - i.e. to support the low-income families with children. 
A highly widespread instrument is a use of specific allowances related to a child care. These include in particular allowances for a home care (own or with babysitters), child education, health care for family members, etc. These instruments may be via caps on the deducted volumes targeted on the lower- and middle-income groups while stimulating the "desirable" behaviour with far lower costs than direct transfer payments. However, it is not technically possible, respectively usual, for such reliefs to be used only by low-income households - and therefore they simultaneously support also more well-off families.

Progressively increasing tested or untested family benefits have similar advantages as progressively increasing tax base allowances or tax credits. However, their primary disadvantage when compared to fiscal instruments is the failure to directly stimulate towards an economic activity.

The rest of the introduced instruments (differentiated rates or brackets for the families with children, insurance premia reliefs via allowances or credits) are in the praxis rather marginal. Interference with structural elements of insurance is in continental Europe risky for two reasons. First, they may very significantly affect the budget revenues, since insurance gradually becomes a source of tax revenues that is more important than personal income taxes. Secondly, insurance premia are in most cases designed on a much simpler basis than personal income taxes and provided the governments seek to oversee uncomplicated tax systems, one of the possibilities is not to increase the complexity of social security contributions.

There are two research approaches towards the issue of an interaction of tax and benefit systems and their links to the behaviour of households. One focuses on the distribution aspects - i.e. taxation/support of the families with children and the impact of tax and benefit systems on the poverty or wealth of the families with children vis-à-vis other families. The second, more extensive course focuses on analysing the impact of taxes and benefits on the economic activity and family behaviour.

With respect to the issue of the microeconomic fundament of a family behaviour, generally available is a fresh overview in Loužek (2010) while the corresponding macroeconomic treatment is given in Loužek (2005). The latest analysis of the distribution of income support is for the United 
States given by Moffitt and Scholz (2010). Analysis of the impact of marriage and family-oriented government measures implemented over the past decades was carried by Arltová and Langhamrová (2009). Tvrdoň (2008) deals with the overall view on institutional aspects of the labour market and summarises selected studies on the issue of labour taxation and unemployment benefits. Večerník (2007) focused on the overall analysis of the Czech labour market. Pavel, Vítek et al. (2010) focused, among other things, on evaluation of the relationship between the size of family-type benefits and the poverty rate of households with children in the EU countries and demonstrated a relatively high correlation between the volume of benefits and poverty. Schneider and Jelínek (2005 and 2001) analysed distributive impacts of the Czech social security and tax system in 2000s.

In general, the economic theory postulates and empirical testing usually confirms the negative relationship between taxation and willingness to work or to hire labour; this destimulative effect is expected also for benefits that are not tied to an economic activity - Alesina and Perotti (1997), Daveri and Tabellini (2000), Nickell (2003), Behar (2009). Fialová and Myslíková (2009) discuss the impact of social benefits in the Czech Republic and other European countries on the labour market participation. Dolenc and Laporšek (2010) analysed effects of the tax wedges on the labour and employment growth in the European Union. Pavel and Vítek (2007) analysed marginal effective tax rates (METR) of employees in the Czech Republic and Slovakia during the transition period and showed that the labour markets in both countries were hit by destimulative METR values, although Slovakia carried reforms that limit the extreme METR values sooner than the Czech Republic. The same authors also showed (Vítek and Pavel, 2007) that the distribution of high METR values is clearly skewed towards single mothers with children and that the overall number of such affected households ranges up to 3-5\% of the total number of families in the Czech Republic. Using the correlation coefficient, OECD (2006) highlights as the most important factor affecting employment the tax wedge (its coefficient is over 0.6, other factors, except for expenditures on the active employment policy, record significantly lower values). Galuščák and Pavel (2005) dealt with the incidence of unemployment and inactivity traps in the Czech Republic and proved that the values of monitored indicators do not represent for the overall supply side of the Czech labour market any particular problem. 
The issue of recycling the tax revenues from newly introduced environmental taxes towards reduction of social security contributions was dealt with by Pavel and Vítek (2008), in the broader context of the modelling of impacts in turn by Chewpreecha et al. (2009). These analyses showed that due to the low revenue from environmental taxes is the "double dividend concept" in the case of the Czech Republic and Slovakia rather hypothetical and the recycling will not have any significant impacts on the employment and work effort. To strengthen these effects, it would be necessary to boost the revenues from environmental taxes and further reduce the premia.

As stated by Dolenc and Laporšek (2010), although the negative effect of taxes on the employment is usually confirmed, intensity of this effect depends upon other factors, such as minimum wages, unemployment benefits, tax incidence share between employers and employees, skill level of the labour force, real wage rigidity and prevailing structure of wage bargaining, and other market policies and institutions.

\section{Tax and Benefit Stimuli of the Families with Children}

Using tax and insurance systems, the families with children are in developed countries usually treated preferentially. Building e.g. on the statistics and methodology of the OECD, we may use various indicators measuring tax and benefit systems in terms of their different impact on family types. In accordance with the established methodology, families may be divided into types, e.g. into individuals without children and with an average income 1 (AW)-0-0, individuals with two children 1 (AW)-0-2, childless couples with one earning partner $1(\mathrm{AW})-1(0)-0$, or couples with children when e.g. the first partner earns the average income level and the other partner's income is e.g. at 66\% AW 1(AW)-1(66\%)-2.

For purposes of an international comparison, among basic indicators may be used 'all-in' tax rates (OECD 2011 and 2011). The 'all-in' tax rate is calculated as a combined central and sub-central government income tax plus employee social security contributions, as a percentage of the gross wage earnings. The calculation takes into account basic/standard income tax allowances and tax credits. 
Tab. 1: 'All-in' average personal income (PIT) and social security contributions (SSC) rates at average wage (AW) by family type, 2010, in \%

\begin{tabular}{|c|c|c|c|c|c|c|}
\hline \multirow{3}{*}{ Country } & \multicolumn{2}{|c|}{ Single } & \multicolumn{2}{|c|}{$\begin{array}{c}\text { One-earner } \\
\text { Married couple }\end{array}$} & \multirow{2}{*}{$1-4$} & \multirow{2}{*}{$4 / 1$} \\
\hline & no child & $\begin{array}{c}\text { two } \\
\text { children }\end{array}$ & no child & $\begin{array}{c}\text { two } \\
\text { children }\end{array}$ & & \\
\hline & 1 & 2 & 3 & 4 & 5 & 6 \\
\hline Finland & 29.1 & 29.1 & 29.1 & 29.1 & 0.0 & 1.0 \\
\hline Hungary & 31.2 & 31.2 & 31.2 & 31.2 & 0.0 & 1.0 \\
\hline Sweden & 24.7 & 24.7 & 24.7 & 24.7 & 0.0 & 1.0 \\
\hline Greece & 18.8 & 17.2 & 20.0 & 18.8 & 0.0 & 1.0 \\
\hline United Kingdom & 25.5 & 24.0 & 25.5 & 24.0 & 1.6 & 1.1 \\
\hline Austria & 33.1 & 30.8 & 32.1 & 30.8 & 2.2 & 1.1 \\
\hline Norway & 28.7 & 26.2 & 26.2 & 26.2 & 2.6 & 1.1 \\
\hline Denmark & 38.6 & 38.6 & 34.4 & 34.4 & 4.3 & 1.1 \\
\hline Netherlands & 31.9 & 22.3 & 28.1 & 28.1 & 3.8 & 1.1 \\
\hline France & 27.8 & 22.5 & 23.9 & 21.9 & 5.9 & 1.3 \\
\hline Italy & 29.8 & 25.1 & 27.3 & 22.9 & 6.9 & 1.3 \\
\hline Slovenia & 33.1 & 27.0 & 29.4 & 24.7 & 8.3 & 1.3 \\
\hline Poland & 24.6 & 17.8 & 23.1 & 17.8 & 6.7 & 1.4 \\
\hline Belgium & 42.1 & 38.4 & 32.9 & 30.3 & 11.7 & 1.4 \\
\hline Switzerland & 16.0 & 11.2 & 12.7 & 10.7 & 5.3 & 1.5 \\
\hline Spain & 21.6 & 15.3 & 17.8 & 14.0 & 7.6 & 1.5 \\
\hline Portugal & 22.9 & 20.1 & 17.1 & 14.9 & 8.0 & 1.5 \\
\hline Luxembourg & 26.4 & 22.1 & 16.5 & 16.5 & 9.9 & 1.6 \\
\hline Estonia & 19.4 & 15.6 & 15.6 & 11.9 & 7.6 & 1.6 \\
\hline Ireland & 21.8 & 15.5 & 15.5 & 13.2 & 8.6 & 1.7 \\
\hline Germany & 39.2 & 26.8 & 31.0 & 19.6 & 19.6 & 2.0 \\
\hline Slovak Republic & 21.5 & 16.2 & 13.4 & 8.2 & 13.3 & 2.6 \\
\hline Czech Republic & 22.5 & 14.4 & 13.9 & 5.8 & 16.7 & 3.9 \\
\hline
\end{tabular}

Source: own calculations, data from OECD (2011a).

In a situation when the head of the household earns an average income, only three countries in Europe (Finland, Sweden, Hungary) do 
not prefer through the tax and insurance system the families with children (there is no difference between 'all-in' tax rates for a single and 1-1(0)-2 family). On the other hand, intensity of the support measured this way is the highest in the Czech Republic, Slovakia and Germany, where the taxation of singles is 2-4 times higher than the taxation of the families with children.

A more complex view that includes both taxes/insurance premia and the benefits provides the following table. 'All-in' less cash transfers according to OECD (2011 and 2011a) include the combined central and sub-central government income tax plus employee social security contributions, less family benefits (in respect of dependent children) paid by the general government as universal cash transfers, as a percentage of the gross wage earnings. The 'all-in less cash transfers' results include cash transfers paid normally in respect of dependent children between five and twelve years of age who attend school.

Tab. 2: 'All-in' average personal income and social security contributions rates at $\mathrm{AW}$ less cash transfers on dependent children by family type, 2010, in \%

\begin{tabular}{|l|r|r|r|r|r|r|}
\hline \multirow{2}{*}{ Country } & \multicolumn{2}{|c|}{ Single } & \multicolumn{2}{c|}{$\begin{array}{c}\text { One-earner } \\
\text { Married couple }\end{array}$} & \multirow{2}{*}{$\mathbf{1}$ - 2 } & \multirow{3}{*}{$-\mathbf{4}$} \\
\cline { 2 - 7 } & no child & $\begin{array}{c}\text { two } \\
\text { children }\end{array}$ & no child & $\begin{array}{c}\text { two } \\
\text { children }\end{array}$ & & \\
\cline { 2 - 7 } Greece & 1 & 2 & 3 & 4 & \multicolumn{1}{c|}{5} & \multicolumn{1}{c|}{6} \\
\hline Spain & 18.8 & 17.2 & 20.0 & 18.8 & 1.6 & 1.2 \\
\hline Netherlands & 21.6 & 15.3 & 17.8 & 14.0 & 6.3 & 3.8 \\
\hline Norway & 31.9 & 18.1 & 28.1 & 23.8 & 13.9 & 4.3 \\
\hline Poland & 28.7 & 18.5 & 26.2 & 21.0 & 10.2 & 5.1 \\
\hline France & 24.6 & 17.8 & 23.1 & 17.8 & 6.7 & 5.3 \\
\hline $\begin{array}{l}\text { United } \\
\text { Kingdom }\end{array}$ & 27.8 & 18.1 & 23.9 & 17.5 & 9.7 & 6.3 \\
\hline Finland & 25.5 & 19.0 & 25.5 & 19.0 & 6.5 & 6.5 \\
\hline Denmark & 29.1 & 19.6 & 29.1 & 22.5 & 9.5 & 6.6 \\
\hline Sweden & 28.6 & 21.2 & 33.7 & 27.1 & 17.5 & 6.6 \\
\hline
\end{tabular}




\begin{tabular}{|l|r|r|r|r|r|r|}
\hline \multirow{2}{*}{ Country } & \multicolumn{2}{|c|}{ Single } & \multicolumn{2}{c|}{$\begin{array}{c}\text { One-earner } \\
\text { Married couple }\end{array}$} & \multirow{2}{*}{$\mathbf{1}-\mathbf{2}$} & \multirow{3}{*}{$-\mathbf{4}$} \\
\cline { 2 - 7 } & no child & $\begin{array}{c}\text { two } \\
\text { children }\end{array}$ & no child & $\begin{array}{c}\text { two } \\
\text { children }\end{array}$ & & \\
\cline { 2 - 7 } Portugal & 1 & 2 & 3 & 4 & \multicolumn{1}{c|}{5} & \multicolumn{1}{c|}{6} \\
\hline Estonia & 22.9 & 13.7 & 17.1 & 9.5 & 9.3 & 7.5 \\
\hline Switzerland & 19.4 & 6.0 & 15.6 & 7.1 & 13.4 & 8.6 \\
\hline Italy & 16.0 & 3.3 & 12.7 & 2.8 & 12.7 & 9.9 \\
\hline Slovak Republic & 29.8 & 19.3 & 27.3 & 17.1 & 10.5 & 10.2 \\
\hline Belgium & 42.1 & 10.5 & 13.4 & 2.4 & 11.0 & 11.0 \\
\hline Germany & 39.2 & 29.7 & 32.9 & 21.6 & 12.4 & 11.3 \\
\hline Ireland & 21.8 & 6.4 & 31.0 & 19.6 & 12.4 & 11.4 \\
\hline Hungary & 31.2 & 16.7 & 31.2 & 18.1 & 14.5 & 13.1 \\
\hline Austria & 33.1 & 17.9 & 32.1 & 17.9 & 15.1 & 14.2 \\
\hline Luxembourg & 26.4 & 6.6 & 16.5 & 1.0 & 19.8 & 15.5 \\
\hline Czech Republic & 22.5 & 4.9 & 13.9 & -5.5 & 17.6 & 19.4 \\
\hline Slovenia & 33.1 & 17.0 & 29.4 & 9.9 & 16.1 & 19.4 \\
\hline
\end{tabular}

Source: own calculations, data from OECD (2011a).

All European countries favour the families with children through taxbenefit instruments (whether in single parent or complete families). As for single parents with vs. without children, in Luxembourg, the Czech Republic and Switzerland is the preferential treatment of children very strong - taxation of individuals without children is in these countries 4-5 times higher. When comparing families with a non-earning partner and two children/without children, the strongest support is provided in Switzerland, Slovakia, Luxembourg and the Czech Republic - in these countries is the taxation of couples 1-1(0) after deduction of transfers associated with children always multiple times higher than the taxation minus benefits of identical couples with children.

Developed countries in Europe implemented over the past 10 years (between 2000-2010) changes in the taxation that usually led to a reduction in the 'all-in' average rate (according to the family type, the average reduction for the monitored countries by 1.5-2.3 percentage points, in the following chart shown only for a family with two children 
and no earning partner 1-0-2 where all OECD countries recorded on average a decline of 2.3 percentage points). As main sources of this decline may be labelled in particular:

- reduction in personal income tax rates,

- in some cases introduction of non-wastable tax credits (e.g. in the Czech Republic),

- indexation of tax allowances or tax credits, particularly for the families with children.

In a rather opposite direction behaved the social security insurance which rates have in recent years rather increased and into play also enters the fact that for the monitored income level do not apply ceilings on insurance premia payments. Due to the construction of a tax base for social security contributions it is not event possible to assume a positive impact of changes in allowances or credits (these elements are in the domain of insurance exceptional). Overall, the 'all-in' average rate has decreased over the past ten years in 21 OECD countries, in 12 countries it has increased and in one country it has remained unchanged.

Countries which have recorded a strong decline in the 'all-in' average rate (the Czech Republic, Israel), or contrariwise its growth (Japan, Mexico) nevertheless frequently carried active reforms in family benefits (in respect of dependent children). For example, the Czech Republic has in the period 2000-2010 significantly reduced taxation of the families with one earning person and two children, and simultaneously it has in 2000-2008 increased benefits to these families. Nevertheless, in the years 2008-2010 there already becomes evident the reform (tightening) of benefit systems that results in tightening of the situation of the families with children (the 'all-in' rate less transfers increased for the past two years by more than one percentage point). 
Fig. 1:'All-in' average personal income and social security contributions rates at $\mathrm{AW}$ less cash transfers on dependent children by family type (changes between 2010, 2008 and 2000)

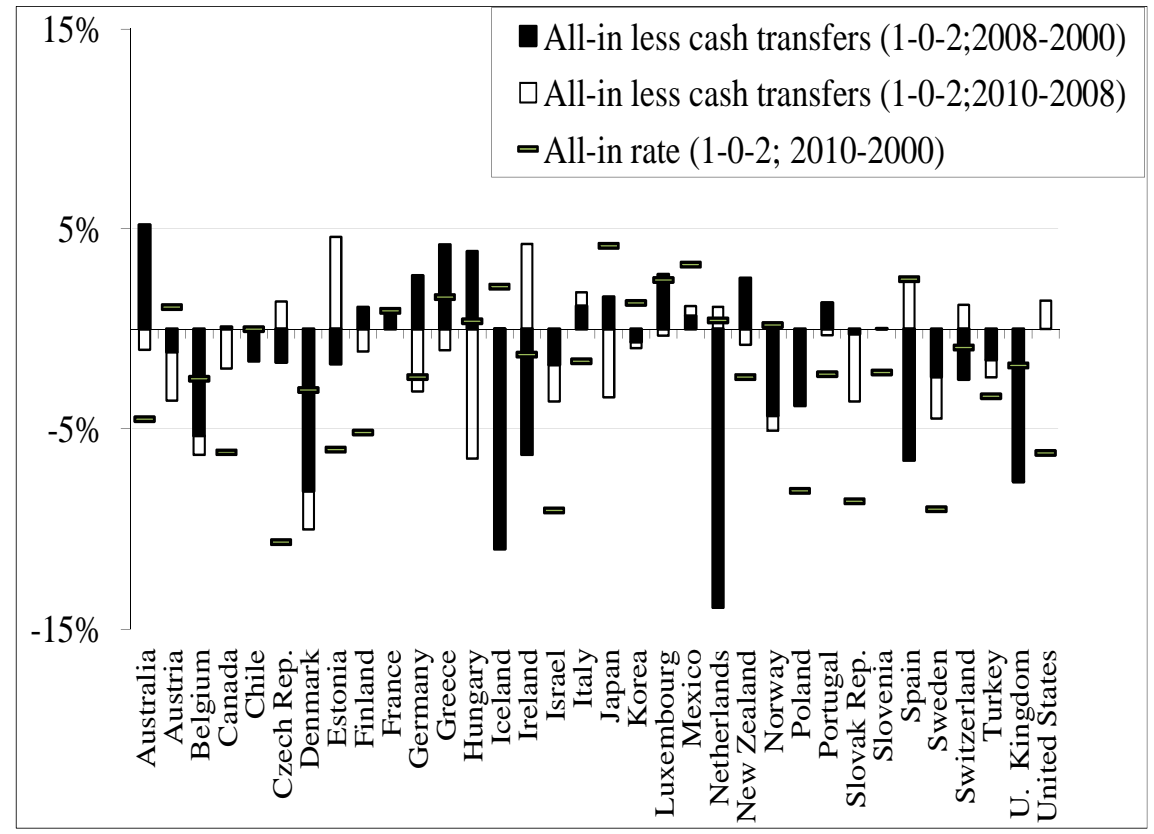

Source: OECD (2011a) and own calculations.

Among countries that over the past decade performed the largest changes of the tax and benefit systems towards the support of the families with children are Netherlands, Iceland, Denmark and the United Kingdom. On the contrary, the strongest negative changes were introduced in Australia, Estonia and Ireland. The Czech Republic has generally in all performed comparisons one of the highest assistances to the families with children via tax and benefit systems.

During the years of a slowdown in the economic growth and a recession (2008-2010) were introduced various changes to the tax and benefit systems. Some countries have significantly increased taxation, respectively reduced benefits to the families with children (Estonia, Ireland and Spain), while other strongly supported families (Hungary, Germany, Japan, Slovakia). In principle there are two assumptions about the behaviour of countries during the economic recession. First, countries try to consolidate their public finances, even at the cost of higher taxes or 
reduced benefits to the families with children. The second possibility is that the governments tried to encourage potential demand by e.g. higher support of the low- and middle-income families with children.

Fig. 2: Changes in the GDP vs. changes in the 'all-in' tax less benefits, 2010-2008 (OECD, constant prices in PPP, 1-0-2, AW)

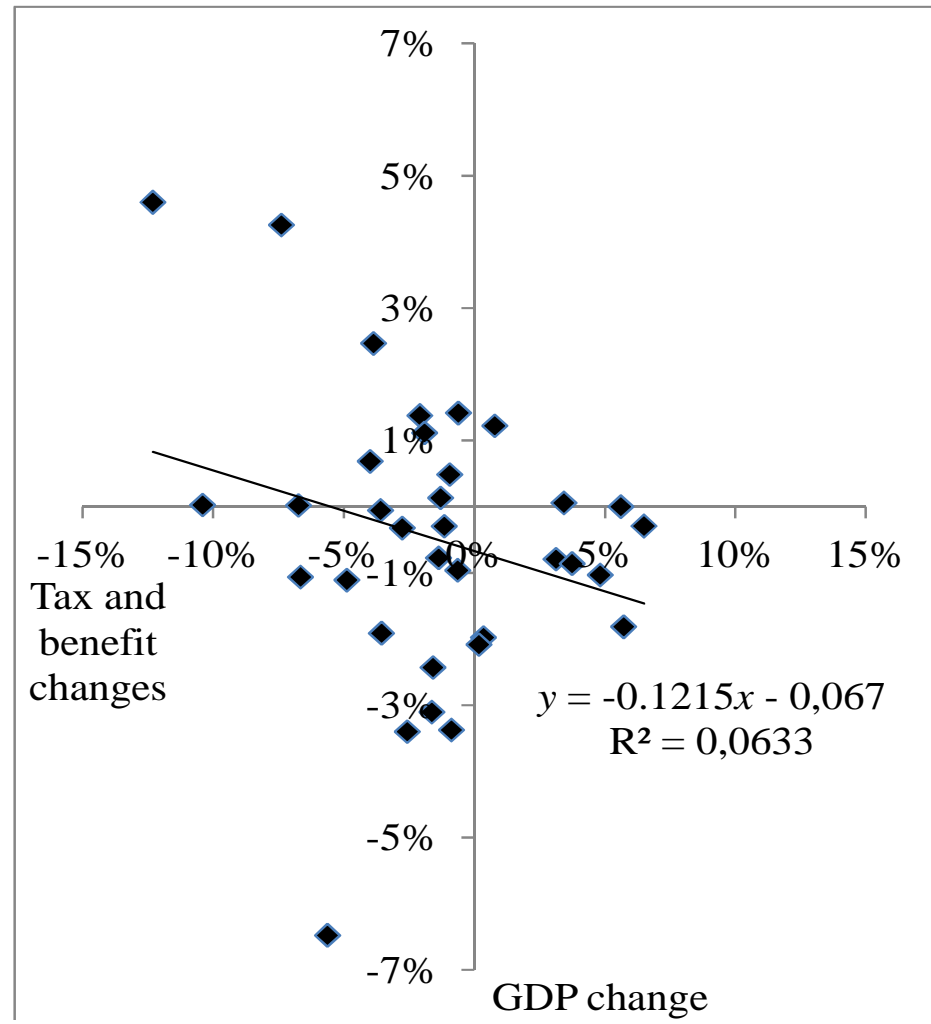

Source: OECD (2011a) and own calculations.

The analysis carried in the previous chart for the GDP at constant prices shows that there is no clear dependence in the behaviour of governments and that neither of the above stated hypotheses can be confirmed. Provided we assume the change in the GDP at current prices (because taxes and benefits are imposed or paid, respectively, also at current prices), the result is similar - it is not possible to establish any dependence. An abrupt shift in the case of Hungary (-6.4\%) may rather as a reaction to the economic cycle be explained as a change in the government. In contrast, changes in Spain and Ireland are rather related to 
the economic recession and budgetary problems. Nevertheless, it is clear that countries which were not subjected to a dramatic fall in the GDP (or did not experience any decline in GDP) did not burden the families with higher taxes or lower benefits.

\section{Changes in the Tax and Benefit Systems in Selected Countries}

For the analysis of impacts of taxes and benefits on the families with children are used also other indicators. The study by Pavel, Vítek et al. (2010) summarises them into the following groups:

1. macroeconomic tax and benefit indicators (share of the premia and personal income taxes on the GDP or a share of the tested and non-tested family benefits on the GDP),

2. microeconomic tax and benefit indicators that include

a) marginal effective tax rates $(\operatorname{METR}(\mathrm{EP}))$,

b) average effective tax rates (AETR).

Marginal effective tax rate measures by how much will the volume of taxes, insurance premia and social benefits change provided the gross earned income increases by a unit. This indicator may be written as follows:

$$
\operatorname{METR}(E P)=1-\frac{\delta N E I}{\delta G E I},
$$

where $\operatorname{METR}(E P)=$ marginal effective tax rate of employed persons,

$\delta N E I \quad=$ change in the net earned income,

$\delta G E I \quad=$ change in the gross earned income.

Using this indicator, it is possible to evaluate (de)motivative impact of taxes and benefits on a change in the work effort.

The second major indicator is the average effective tax rate (sometimes is used only the term average tax rate - ATR). This rate measures the overall impact of social benefits, income taxes and insurance premia on the total income of a working employee. 


$$
\operatorname{AETR}(E P)=1-\frac{N E I}{G E I}=1-\frac{G E I-I T-S S C-F B+O S B}{G E I},
$$

where $\operatorname{AETR}(E P)=$ average effective tax rate of employed persons,

$N E I=$ net earned income,

GEI = gross earned income,

IT = personal income taxes,

SSC = social security contributions,

$F B \quad=$ non-tested family benefits,

$O S B=$ other social benefits.

Positive ATR means that the given subject pays overall more (in taxes and insurance premia) than it receives (in benefits). Negative ATR represents the opposite situation. This indicator may be further decomposed into the average rates of (i) income taxes (AIT), (ii) insurance premia (ASSC), (iii) overall tax-levy burden (ATR), (iv) family benefits (AFB) and (v) all social benefits (ASB).

Pavel, Vítek et al. (2010) analysed all the above indicators for the years 2001-2008 and found that between 2001-2009 there cannot be established nether for AETR nor for ATR any clear trends for the developed countries with respect to the taxation of the low-income families with children. Nevertheless, identified can be countries which over the past decade recorded a significant change in average effective tax rates or in average tax rates.

For a more detailed analysis of these countries it is necessary to describe and compare their main changes in the tax and benefit systems. Specifically, we will focus on changes that have a direct impact on the families with children or that are designed primarily for the families with children. Within the following section of this chapter is therefore for selected countries carried a basic analysis of the structural changes in main parameters of their tax and benefit systems. The main data sources represent statistics and publications of the OECD.

Over the past decade, average effective tax rates have risen on average by about 2 percentage points, mainly due to the decline in family benefits (about 1 percentage point) and also due to the rise in insurance premia (about 0.5 percentage points). Income taxes remained rather constant. The Czech Republic has over the past 10 years increased the AETR of the families with children. There has been a significant 
reduction in personal income taxes through high credits for children combined with the possibility of a non-wastable tax credit, but reduced were also child benefits, respectively income limits that allowed their awarding. This way, AETR in the Czech Republic approached the average values in developed countries.

\section{Tab. 3: Changes in indicators of a burden/support of the families with children (between 2008 and 2001)}

\begin{tabular}{|l|l|r|r|}
\hline Family type & Indicator & $\begin{array}{c}\text { OECD - } \\
\text { Europe (avg.) }\end{array}$ & Czech Republic \\
\hline Family 1-0-2 & AETR & 2.4 & 18.2 \\
\cline { 2 - 4 } & ATR & 0.3 & -6.5 \\
\cline { 2 - 4 } & AFB & -1.5 & -16.2 \\
\hline Family 2-0-2 & AETR & -0.1 & 1.6 \\
\cline { 2 - 4 } & ATR & -0.1 & -4.1 \\
\cline { 2 - 4 } & AFB & -0.4 & -5.4 \\
\hline Family 1-1-2 & AETR & 2.1 & 15.4 \\
\cline { 2 - 4 } & ATR & -0.3 & -11.2 \\
\cline { 2 - 4 } & AFB & -1.1 & -16.0 \\
\hline
\end{tabular}

* 1-0-2: one parent with income 70\% AW, two children; 2-0-2: two employed parents, first $70 \%$ AW, second $67 \%$ AW, two children; 1-1-2: two parents, only one employed with $70 \%$ AW, two children. AETR = average effective tax rate, ATR = average total tax-levy burden, AFB = average rate of family benefits.

Source: Pavel, Vítek et al. (2010) and OECD (2011 and 2011a).

Ireland $^{1}$ replaced during the monitored period the tax base allowance with a new tax credit. Assuming the standard tax rate, an equivalent to the allowance of IEP 4700 in 2001 would have amounted to the tax credit of EIP 1034 (corresponding to USD 1216). The tax credit was in 2009 EUR 1 830. It is therefore evident that the tax credit within the monitored period did not have a strong impact on a reduction of the tax burden. On the other hand, a significant impact on the growth of net incomes of households with children had a sharp increase in the child benefits from $2.9 \%$ to $5 \%$ of the average wage.

1 Description of individual countries is based on Pavel, Vítek et al. (2010). 
In Ireland also simultaneously declined between the years 2000 and 2010 marginal rates of the personal income tax: from 22, respectively $44 \%$, to 20, respectively $41 \%$ (bracket limit set at IEP 17 000). However, since 2009 has been introduced a surcharge to the personal tax amounting to $2-6 \%$ for incomes above the threshold of EUR 15 028. There was also a slight relative decrease in the second bracket's limit for individuals (from $98 \%$ of the average wage /AW/ to 92\%), for couples with both earning partners (from 196\% AW to $183 \% \mathrm{AW}$ ) and for single parents (from $116 \%$ AW to $102 \%$ AW). Significant for the families with children was also the sharp decline in the second bracket's limit for couples with one earning partner (from $162 \% \mathrm{AW}$ to $114 \% \mathrm{AW}$ ).

Italy recorded a significant increase in the tax credit for a child, nevertheless introduced was a degression with the growth in income related both to the credit for a dependent partner as well as to the child credit while the credit for a dependent partner was not significantly increased. The system of cash benefits for a dependent spouse or a child took into account the family income and a number of dependents. Newly are these benefits available only to the families below a certain level of income or to the families with at least $70 \%$ of income made up by wages or pensions.

Luxembourg over the past decade partly replaced tax base allowances with tax credits for earning persons and pensioners. The non-taxable portion of the tax base of EUR 1920 was replaced with EUR 1416 and a non-wastable tax credit of EUR 300. From the perspective of the family policy is significant that equally treated became marriages and partnerships of people of either opposite or same sex - partnerships are newly taxed in the same way as marriages, i.e. using the joint taxation.

Hungary, among other things, reduced the number of rates, lowered marginal tax rates of the personal income tax and substantially increased limits of the final bracket. Over the monitored period were also tightened conditions applicable on the credits for children - child credit may be used only by the families with three or more children.

In Germany, the system of means tested child benefit was in 1996 replaced by tax credits. As a result, there was a sharp decline in average tax rates (ATR) - e.g. for an employee with an average income and two children the ATR declined from $9.6 \%$ to $1.6 \%$. However, as a result of 
this reform the average tax rate for individuals without children has slightly increased. Among other things, German tax reforms over the past 10 years (Reform 2000) also meant that in 2004 were reduced tax reliefs for single parents to EUR 1308 , reduced were marginal tax rates via adjustment of the calculation formula. The changes resulted in a decrease in the burden of the medium-income families with children. Carried was also an indexation of the basic allowance and limits of brackets.

Netherlands replaced in 2001 allowances with credits and reductions in rates and introduced an additional credit for the families with children. In 2002 and 2003 has been introduced an additional, so-called combined, credit and in 2006 the child credits were consolidated. In 2008 the child credit was replaced by an additional child credit. In 2009 was the tax credit reduced for low-income partners who will be in 2024 able to apply their credit only towards their income. Newly introduced was a combined credit for income-dependent partners and single parents with a view of stimulating their participation in the labour market. Since 2009 it is possible to receive additional, income-dependent child allowance.

The following table summarises development of the main elements of the taxation of personal incomes in the covered countries.

Tab. 4: Changes in the main parameters of personal income taxes 2000-2010

\begin{tabular}{|c|c|c|c|c|c|c|c|}
\hline Country & Year & 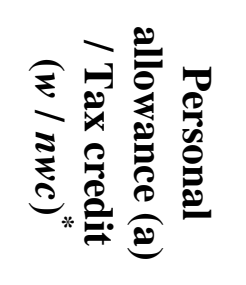 & 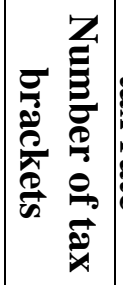 & 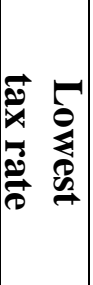 & 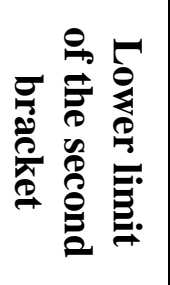 & 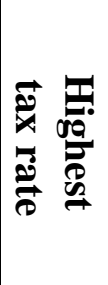 & م \\
\hline \multirow[t]{2}{*}{ Ireland } & 2000 & $1034(\mathrm{wc})$ & 2 & 22.0 & 17000 & 44.0 & 17000 \\
\hline & 2010 & $1830(\mathrm{wc})$ & 2 & 20.0 & 36400 & 41.0 & 36400 \\
\hline \multirow[t]{2}{*}{ Italy ('000) } & 2000 & 2220 & 5 & 18.5 & 20000 & 45.0 & 135000 \\
\hline & 2010 & 1840 & 5 & 23.0 & 15000 & 43.0 & 75000 \\
\hline \multirow[t]{2}{*}{ Luxembourg } & 2000 & 1353.5 & 17 & 0 & 270000 & 46.0 & 2640000 \\
\hline & 2010 & $\begin{array}{r}1416 \\
(\mathrm{a})+300(n w c) \\
{[2.5 \%]^{* *}}\end{array}$ & 16 & 0 & 11265 & 38.0 & 39885 \\
\hline
\end{tabular}




\begin{tabular}{|c|c|c|c|c|c|c|c|}
\hline Country & Year & 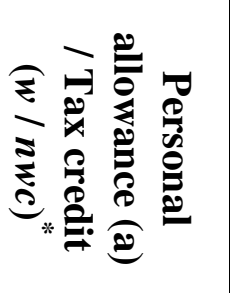 & 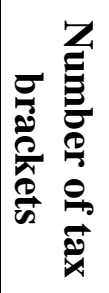 & 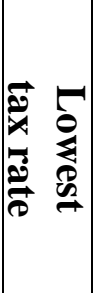 & 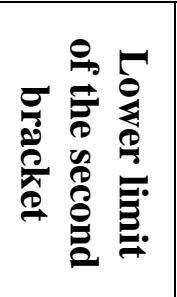 & 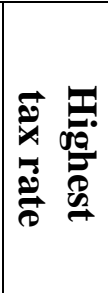 & 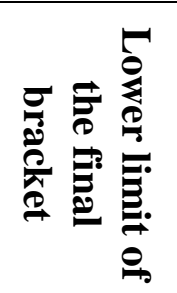 \\
\hline \multirow[t]{2}{*}{ Hungary } & 2000 & 0.0 & 3 & 20.0 & 400000 & 40.0 & 1000000 \\
\hline & 2010 & 0.0 & 2 & 18.0 & 1900000 & 36.0 & 1900000 \\
\hline \multirow[t]{2}{*}{ Germany $^{* * *}$} & 2000 & 0.0 & 3 & 0.0 & 13500 & 51.0 & 114696 \\
\hline & 2010 & $\begin{array}{r}0.0 \\
{[5.5 \%]^{* *}}\end{array}$ & 3 & 0.0 & 8004 & 45.0 & 250730 \\
\hline \multirow[t]{2}{*}{ Netherlands } & 2000 & 8949 (a) & 4 & 4.5 & 15257 & 60.0 & 107757 \\
\hline & 2010 & 1987 (a) & 4 & 2.3 & 18218 & 52.0 & 54367 \\
\hline
\end{tabular}

* Wastable tax credit/non wastable tax credit. ${ }^{* *}$ Surtax rates determined as a percentage of central government tax measured gross of tax credits. ${ }^{* * *}$ OECD (PART I. Taxation of Wage Income (year 2000)): "Germany applies a formula rather than a tax schedule to taxable income above a threshold amount. The first statutory tax rate above the basic threshold in 2000 of DEM 13499 is 22.9 percent, while the top marginal rate is 51 per cent applying to taxable income above DEM 114 696.” For 2010: “...The first statutory tax rate above the basic threshold in 2010 of EUR 8004 is 14.0 percent, while the top marginal rate is 45.0 per cent applying to taxable income above EUR 250730 ."

Source: OECD (2011a) and own calculations.

For international comparison is preferable to use shares of basic income tax parameters on the annual gross average wage (YAW). For example, in Germany was in the monitored year applicable a "border" for the highest nominal marginal tax rate (calculated from the income tax formula used in Germany) $767 \%$ of the average wage while e.g. in Hungary, Luxembourg and Ireland are the highest rates imposed on the tax base already at around $75 \%$ of the average income.

Less variability is observed with respect to the share of allowances/tax credits when, following the recalculation of a credit into an allowance for Ireland using the $20 \%$ rate, the share of allowances on the annual average wage in the monitored countries ranges between 0.0 and $18.9 \%$. On the other hand, it is very difficult to compare parameters such as an allowance or a tax credit since their impact on the net income of taxpayers is completely different. In the systems with progressive tax rates, impact of tax reliefs also varies according to income levels of taxpayers. One of 
possible explanations for the gradual increase in the importance of insurance premia within taxation of individuals or families is indeed in the slow adjustment of parameters - slight increase in rates, absence of ceilings or their faster indexing compared to the wage growth or reductions in lower thresholds.

Tab. 5: Changes in social security contributions of employees (20002009, \% of year average wage YAW)

\begin{tabular}{|c|c|c|c|c|c|}
\hline Country & Year & $\begin{array}{c}\text { Marginal } \\
\text { rate }\end{array}$ & $\begin{array}{c}\text { Lower } \\
\text { threshold } \\
\text { as \% of } \\
\text { YAW }\end{array}$ & $\begin{array}{c}\text { Upper } \\
\text { threshold } \\
\text { as \% of } \\
\text { YAW }\end{array}$ & $\begin{array}{c}\text { Maximum } \\
\text { contribution } \\
\text { as \% of } \\
\text { YAW }\end{array}$ \\
\hline \multirow[t]{4}{*}{ Germany } & \multirow[t]{2}{*}{2009} & 20.7 & & 107.7 & \\
\hline & & 11.4 & 107.7 & 158.3 & 28.1 \\
\hline & \multirow[t]{2}{*}{2000} & 20.5 & & 115.0 & \\
\hline & & 12.9 & 115.0 & 153.4 & 28.5 \\
\hline \multirow[t]{3}{*}{ Hungary } & 2009 & 9.5 & 0.0 & 305.8 & 29.0 \\
\hline & \multirow[t]{2}{*}{2000} & 8.0 & & 186.3 & 14.9 \\
\hline & & 3.0 & & 186.3 & 5.6 \\
\hline \multirow[t]{7}{*}{ Ireland } & \multirow[t]{4}{*}{2009} & 4.0 & 45.3 & 64.4 & \\
\hline & & 6.0 & 64.4 & 128.8 & \\
\hline & & 2.0 & 125.5 & 247.9 & \\
\hline & & 2.5 & 247.9 & & \\
\hline & \multirow[t]{3}{*}{2000} & 4.5 & 22.9 & 64.2 & \\
\hline & & 6.5 & 64.2 & 116.9 & \\
\hline & & 2.0 & 116.9 & & \\
\hline \multirow[t]{4}{*}{ Italy } & \multirow[t]{2}{*}{2009} & 9.5 & & 152.4 & \\
\hline & & 10.5 & 152.4 & 331.5 & 33.2 \\
\hline & \multirow[t]{2}{*}{2000} & 9.2 & & 161.6 & \\
\hline & & 10.2 & 161.6 & 351.6 & 34.2 \\
\hline \multirow[t]{4}{*}{ Luxembourg } & \multirow[t]{2}{*}{2009} & 11.0 & & 209.2 & 22.9 \\
\hline & & 1.4 & 10.5 & & \\
\hline & \multirow[t]{2}{*}{2000} & 11.5 & & 202.0 & 23.3 \\
\hline & & 1.0 & 10.1 & & \\
\hline
\end{tabular}




\begin{tabular}{|c|r|r|r|r|r|}
\hline \multirow{2}{*}{ Country } & Year & $\begin{array}{c}\text { Marginal } \\
\text { rate }\end{array}$ & $\begin{array}{c}\text { Lower } \\
\text { threshold } \\
\text { as \% of } \\
\text { YAW }\end{array}$ & $\begin{array}{c}\text { Upper } \\
\text { threshold } \\
\text { as \% of } \\
\text { YAW }\end{array}$ & $\begin{array}{c}\text { Maximum } \\
\text { contribution } \\
\text { as \% of } \\
\text { YAW }\end{array}$ \\
\hline Netherlands & \multirow{2}{*}{2009} & 0.0 & 37.2 & 108.1 & 0.0 \\
\cline { 3 - 6 } & & 6.9 & & 73.2 & 5.0 \\
\cline { 2 - 6 } & \multirow{2}{*}{2000} & 31.2 & & 72.6 & 22.6 \\
\cline { 3 - 6 } & & 6.3 & 42.0 & 120.7 & 4.9 \\
\cline { 3 - 6 } & & 1.8 & & 81.4 & 1.4 \\
\cline { 3 - 6 } & 29.4 & & 71.0 & 20.9 \\
\hline
\end{tabular}

Source: OECD (2011a) and own calculations.

Within the compulsory insurance of employees, the largest changes were carried in Hungary where the contribution rate increased and at the same time also shifted the upper threshold. Insurance premia have changed against the interest of employees also in Germany (reduction in the lower limit of the second bracket) and in Italy. As a result of these changes, in all countries has increased or stagnated the maximum employee contribution on the social security as a percentage of the annual average wage.

\section{Conclusion}

With respect to low birth rates, developed countries face a question whether to support via fiscal instruments the families with children or not. Analysis carried in this article demonstrates that most developed countries support families using the tax and particularly benefit systems, although in a considerably varied intensity. The Czech Republic ranks with respect to the taxation of incomplete families with children (who are the most at risk in terms of both poverty and the inactivity trap) among the countries that these households support the most.

The analysis did not confirm the assumption that in developed countries there may be for the past two years proven the trend of rising average tax rates for single parent families with children. Although most countries in the period 2000-2010 reduced taxation of these families, changes in benefit systems are not as clear-cut and often acted in the opposite direction, i. e. against the reduction of tax burden. One of the main 
instruments that caused this effect is the restriction of universal, familytype benefits.

Changes in the tax and benefit systems over the past two years did not, on average, follow the changes in the GDP. Although it seems that countries which in 2008-2010 suffered a significant decline in the GDP have more than others set to increase the taxation of the monitored family type, this trend is not particularly strong and cannot yet be clearly proven. As for the different types of families, in developed countries there have over the past decade declined burden by the tax and benefit systems for almost all types of families. Nevertheless, the decrease was on average none too dramatic. The Czech Republic stands out from this trend and the changes adopted in recent years, especially in taxes, resulted in a sharp decline in average tax rates for all types of households. However, in combination with the reduced access to family benefits, the overall average effective taxation (after taking into account the impact of benefits) has in the Czech Republic for certain types of households significantly increased.

\section{References}

[1] Alesina, A. - Ardagna, S. (2010): Large Changes in Fiscal Policy: Taxes versus Spending. Tax Policy and the Economy, 2010, vol. 24, no. 1, pp. 35-68.

[2] Alesina, A. - Perotti, R.(1997): The Welfare State and Competitiveness. American Economic Review, 1997, vol. 87, no. 5, pp. 921-39.

[3] Arltová, M. - Langhamrová, J. (2009): Analýza vztahů časových rad porodnosti a š̌atečnosti v České republice v letech 1960-2007. Politická ekonomie, 2009, vol. 4, no. 4, pp. 495-507.

[4] Behar, A. (2009): Tax Wedges, Unemployment Benefi ts and Labour Market Outcomes in the New EU Members. AUCO Czech Economic Review, 2009, vol. 3, no. 1, pp. 71-94.

[5] Carone, G. - Salomaki, A. (2004): Reforms in tax-benefit systems in order to increase employment incentives in the EU. Brussels, European Commission Economic Paper no. 160, 2004.

[6] Daveri, F. - Tabellini, G. (2000): Unemployment, Growth and Taxation in Industrial Countries. Economic Policy, 2000, vol. 15, no. 30, pp. 47-104. 
Vítek, L.: Fiscal Instruments of a Support of the Families with Children and their Changes in Developed Countries.

[7] Dolenc, P. - Laporšek, S. (2010): Tax Wedge on Labour and its Effect on Employment Growth in the European Union. Prague Economic Papers, 2010, vol. 19, no. 4, pp. 344-358.

[8] Fialová, K. - Mysíková, M. (2009): Labour Market Participation: The Impact of Social Benefits in the Czech Republic and Selected European Countries. Prague Economic Papers, 2009, vol. 18, no. 3, pp. 235-250.

[9] Galuščak, K. - Pavel, J. (2005): Does Work Pay? Incidence of Unemployment and Incactivity Traps in the Czech Republic. European Economy, 2005, no. 2, pp. 179-192.

[10] Chewpreecha, U. - Píša, V. - Pollitt, H. - Ščasný, M. (2009): Analyzing Macroeconomic Effects of Environmental Taxation in the Czech Republic with the Econometric E3ME Model. Finance a úvěr, 2009, vol. 59, no. 5, pp. 460-491.

[11] Jahoda, R. (2004): Interakce sociálního a daňového systému a pracovní pobídky. Praha, Výzkumný ústav práce a sociálních věcí, 2004.

[12] Kubátová, K. (2010): Daňová teorie a politika. Praha, Wolters Kluwer, 2010.

[13] Loužek, M. (2005): Makroekonomické aspekty porodnosti. Politická ekonomie, 2005, vol. 53, no. 6, pp. 733-746.

[14] Loužek, M. (2010): Mikroekonomické základy reprodukčního rozhodování. Politická ekonomie, 2010, vol. 58, no. 3, pp. 374-391.

[15] Moffitt, R. - Scholz, J. K. (2010): Trends in the Level and Distribution of Income Support. Tax Policy and the Economy, 2010, vol. 24, no. 1, pp. 111-152.

[16] Nickell, S. (2003): Employment and Taxes. München, CESifo Working Paper No. 1109, 2003.

[17] OECD (2006): OECD Employment Outlook: Boosting Jobs and Incomes. Paris, Organization for Economic Cooperation and Development, 2006.

[18] OECD (2009): OECD Employment Outlook: Tackling the Job Crisis. Paris, Organization for Economic Cooperation and Development, 2009. 
[19] OECD (2011): Taxing Wages 2009-2010. Paris, Organization for Economic Cooperation and Development, 2011.

[20] OECD (2011a): OECD Tax Database. Paris, Organization for Economic Cooperation and Development, 2011.

[21] Pavel, J. - Vítek, L. (2005): Mezní efektivní daňové sazby zaměstnanců na českém a slovenském pracovním trhu $v$ období transformace. Politická ekonomie, 2005, vol. 53, no. 4, pp. 477-494.

[22] Pavel, J. - Vítek, L. (2008): Revenue Neutral Environmental Tax Reform - Case of the Czech Republic. In: Critical Issues in Environmental Taxation. Oxford, Oxford University Press, 2008, pp. 757-781.

[23] Pavel, J. - Vítek, L. et al. (2010): Komparace daňových, pojistných a dávkových systémů ve vyspělých zemích (OECD) z hlediska jejich vlivu na odvodové zatižení nízkopríjmových domácností. Praha, Vysoká škola ekonomická v Praze, 2010. Unpublished.

[24] Prescott, E. C. (2004): Why Do Americans Work So Much More Than Europeans. Federal Reserve Bank of Minneapolis Quarterly Review, 2004 , vol. 28 , no. 1 , pp. 2-13.

[25] Schneider, O. - Jelínek, T. (2001): Vliv českého sociálního systému a daňových úlev na rozdělení př́jmi̊. Finance a úvěr, 2001, vol. 51, no. 12, pp. 639-657.

[26] Schneider, O. - Jelínek, T. (2005): Distributive Impact of Czech Social Security and Tax Systems: Dynamics in Early 2000s. Prague Economic Papers, 2005, vol. 14, no. 3, pp. 221-237.

[27] Sirovátka, T. - Žižlavský, M. (2003): Nezaměstnanost a pracovní pobídky. Politická ekonomie, 2003, vol. 51, no. 3, pp. 391-406.

[28] Tvrdoň, M. (2008): Institucionální aspekty fungování trhu práce. Politická ekonomie, 2008, vol. 56, no. 5, pp. 621-642.

[29] Večerník, J. (2007): The Czech Labour Market: Historical, Structural and Policy Perspectives. Prague Economic Papers, 2007, vol. 16, no. 3, pp. 220-236.

[30] Vítek, L. - Pavel, J. (2007): Analýza distribuce mezních efektivních dañových sazeb v ČR s využitím SRU. Theoretical and Practical Aspects of Public Finance [CD-ROM]. Praha, Oeconomica, 2007, p. 86. 


\title{
Fiscal Instruments of a Support of the Families with Children and their Changes in Developed Countries
}

\author{
Leoš VÍTEK
}

\begin{abstract}
Governments usually try to use fiscal instruments to support the families with children. However, fiscal instruments also affect the work effort and labour demand. Problems associated with (de)stimulantive effects of taxes, insurance premia and benefits arise, among other things, also due to the fact that because of various reasons, these instruments are not effectively coordinated and often operate in opposite directions. The article analyses changes in fiscal instruments of a support of the families with children in developed countries over the past decade and focuses on the development of selected tax-benefit indicators that describe the fundamental characteristics of the taxation of the families with children. Given that the universal, family-type social benefits often take the form of negative taxes, the paper includes also this type of family benefits. The results of the analysis show that the vast majority of developed countries strongly support the families with children via fiscal instruments. It also turns out that over the past decade the governments have rather reduced effective taxation of the families with children. During the last two years, however, some countries recorded an increase in the taxation of families, including the families with children. Countries that have over the past ten years successfully sought to support the families with children relied on progressive reliefs or benefits targeted at the families with more than two children.
\end{abstract}

Key words: Support of the families with children; Taxes; Family benefits.

JEL classification: E24, H24, J32. 